\title{
The Neo-Confucianism of the Joseon Dynasty: Its Theoretical Foundation and Main Issues
}

\author{
HaeSung LEE*
}

\begin{abstract}
The theoretical foundation of Joseon Neo-Confucianism, which started with the theory of the Principle and Material Force (Seongriseol), seeks for the fundamental values of all things in the universe by means of the theories of Cosmology (Ujuron) and Mind and Nature (Simseongron). The theory of Self-Cultivation (Suyangron) pursues ideal character training to reach the ultimate Noble Gentleman's (Gunja) status; then established the theory of Fidelity (Yiriron), which stresses moral practice against injustice. These theories functioned organically with the theory of Ritual Formalities (Yeseol) and the theory of Statecraft Ideas (Gyeongseron), deeply rooted in Democentrism (Minbonjuyi), in order to realize Confucian ideas as methodological indicators. The theory of Four Beginnings and Seven Emotions (Sadanchiljeongron) extended to be the theories of the Principle's Dominance (Juriron) and Material Force's Dominance (Jugiron). Likewise, the theory of Sameness-Difference of Human Nature and Material Nature (Inmulseong Dongiron) became the Horak debates, which formed the Neo-Confucian academic genealogies of the Joseon dynasty.
\end{abstract}

Keywords: Neo-Confucianism, Joseon dynasty, Korean philosophy, theory of Principle and Material Force

\section{Izvleček}

Teoretske osnove novokonfucijanstva korejske dinastije Joseon, ki so zakoreninjene v teoretskem modelu načela in materialne sile (Seongriseol), vidijo osnovne vrednote vsega bivajočega $\mathrm{v}$ teorijah (Ujuron) ter srčni zavesti in naravi (Simseongron). Teorija samo-kultivacije (Suyangron) opisuje kultivacijo posameznika, katerega značaj naj bi v tem postopku sčasoma dosegel stopnjo plemenitnika (Gunja). Utemeljena je tudi na teoriji zvestobe oziroma lojalnosti (Yiriron), ki poudarja moralno prakso in si prek nje prizadeva odpraviti nepravičnost. Te teorije so delovale skladno s teorijo obrednih formalnosti (Yeseol) in teorijo državnosti (Gyeongseron) in so temeljile na ideji democentrizma (Minbonjuyi) ter si prizadevale za uresničevanje konfucijanskih idej v smislu metodoloških premis. Teorija štirih kalčkov in sedmih občutij (Sadanchiljeongron) se je razširila in vključila tudi teorijo

\footnotetext{
* HaeSung LEE, Professor, Chief of Korean studies, Institute of Classical, Mediterranean and Oriental Studies, University of Wroclaw, Poland. hslees[at]yahoo.co.kr
}

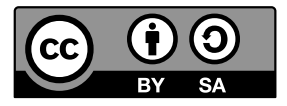


prevlade materialne sile (Juriron). Na podoben način je v razprave prišla še teorija človeške in materialne narave (Inmulseong Dongiron) in oblikovala se je genealogija dinastije Joseon. Ključne besede: neo-konfucijanstvo, dinastija Joseon, korejska filozofija, teorija načela in materialne sile

\section{Introduction: Joseon- the Ideal State of Confucian Ideology}

Founded in Confucian ideals, the Joseon dynasty (朝鮮 1392-1910) was a completely differentiated state, in which all the social norms were integrated with the ruling ideology-difficult to find such a case in other civilizations around the world. All Five Confucian Constant Virtues (Osang 五常, Chin. Wuchang) ${ }^{1}$ were included in the names of key buildings to reflect the idea in all directions of Seoul, the capital city.

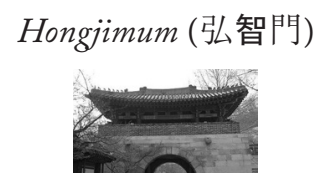

Gate of Wide Wisdom

Donyimun (敦義門)

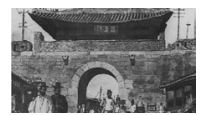

Gate of Abundant

Righteousness
Bosingak (普信閣)

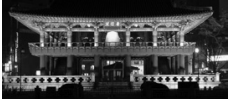

Pavillon of Spreading Trust

Sungnyemun (崇禮門)

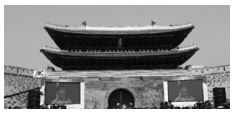

Gate of Exalted Rituals

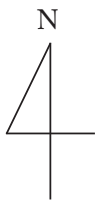

Heunginjimun (興仁之門)

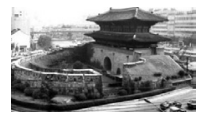

Gate of Rising

Benevolence

Figure 1: Buildings symbolized the Confucian core values in Seoul (Source: author's own work)

Moreover, the main royal buildings were also named by Jeong Dojeon (鄭道傳, 1342-1398) ${ }^{2}$, who was the founding contributor of the dynasty: Gyeongbok Gung (景 福宮)—the Main Palace of the dynasty; Kwanghwa Mun (光化門)— the Main Gate

1 They are: Benevolence (In 仁, Chin. Ren), Righteousness ( $Y i$ 義, Chin. Yi), Propriety/Rituals (禮 $Y e / R y e$, Chin. Li), Wisdom ( $j i$ 智, Chin. Zhi), and Trustworthiness (Sin 信, Chin. Xin).

2 He was the principal architect of the Joseon regime-laying down its ideological, institutional, and legal framework, which would govern it for five centuries (Lee 2014). 
of the palace; and KeunjeongJeon (勤政殿)—the Throne Hall for court audiences and foreign envoys. "Gyeongbok" means "to pray for the great fortune of peaceful reign for the kings, royal family and the people". "Kwanghwa" means "the kings" great virtue illuminates the whole country". It is the abbreviation of "Kwangcheon Hwail" (光天化日), which means "the world of bright prospect" and "peaceful period". Apart from that, "Keunjeong" means "to rule with sincerity and diligence" which was quoted by Jeong Dojeon in the Book of Documents (Seogyeong 書經, Chin. Shujing).

Likewise, The Neo-Confucianism of the Joseon dynasty, which set up the state framework and led social order as its absolute value system, which thrived as a central ideology through the rise and fall of the country for more than five hundred years.

\section{The Theoretical Foundation of Neo-Confucianism}

Joseon Neo-Confucianism was based on the philosophy of metaphysical, nominal, and practical speculation. The theoretical foundation of Joseon Neo-Confucianism, which started with the "theory of Principle and Material Force" (Seongriseol 性理說, Chin. Xinglishuo), seeks for the fundamental values of all things in the universe by means of the theories of Cosmology (Ujuron 宇宙論, Chin. Yuzhoulun) and Mind and Nature (Simseongron 心性論, Chin. Xinxinglun).

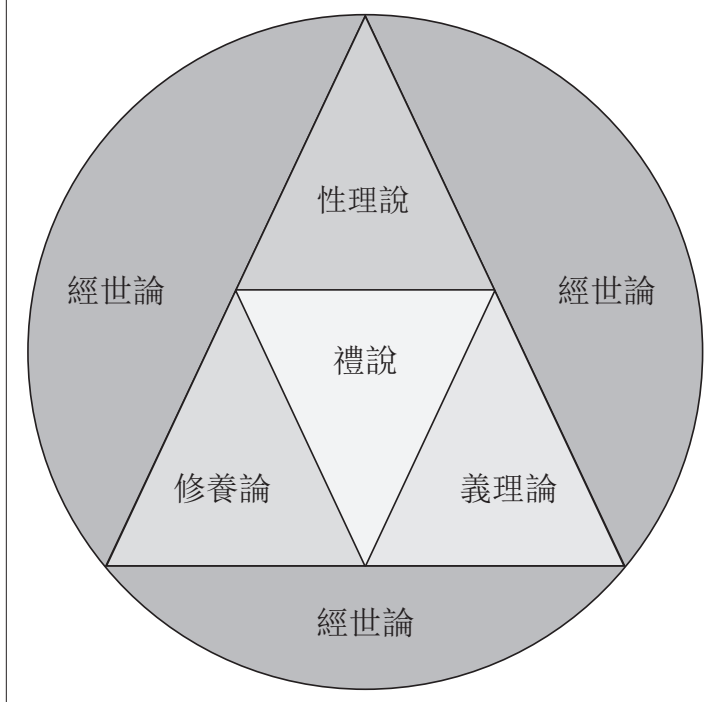

Theory of Priciple and Material Force (Seongriseol 性理說)

Theory Self-Cultivation

(Suyangron 修養論)

Theory of Fidelity

(Yiriron 義理論)

Theory of Statecraft Ideas

(Gyeongseron 經世論)

Theory of Ritual Formalities

(Yeseol 禮說)

Figure 2: Theoretical foundation of Joseon Neo-Confucianism (Source: author's own work.)

3 Classic of Poetry (Sigyeong 詩經, Chin. Shijing), Part Daya (大雅). “皖醉以酒 朁飽以德 君子萬年 介爾景福”. 
Subsequently, it gave birth to the theory of Self-Cultivation (Suyangron 修養論, Chin. Xiuyanglun), which pursues ideal character training to reach the ultimate Noble Gentleman's status; then established the theory of Fidelity (Yiriron 義理論, Chin. Yililun), which emphasizes moral practice against injustice. Moreover, these theories functioned organically with the theory of Ritual Formalities (Yeseol 禮 說, Chin. Lishuo), which constructs proper human relationships and social orders, and the theory of Statecraft Ideas (Gyeongseron 經世論, Chin. Jingshilun), deeply rooted in Demo-Centrism (Minbonjuyi 民本主義, Chin. Minbenzhuyi) in order to realize Confucian ideas as methodological indicators.

\section{Theory of Principle and Material Force}

"Neo-Confucianism" is a general term commonly applied to the revival of the various strands of Confucian philosophy during the Chinese Song dynasty (宋 960-1280 CE). Zhu Xi (朱喜, 1130-1200 CE) was by far the most well-known scholar, and is pretty representative of "mainstream" Neo-Confucian thought- the "theory of Principle and Material Force" (Seongriseol 性理說). There are two main theoretical foundations in the theory. The first one is "Cosmology". It came from speculations on questions like: "What is the universe made of?", namely, "What is the universe composed of?", or "What are the most fundamental particles of the Universe?" Zhu Xi explained that the unique source of the whole universe is called the "Supreme Ultimate" (太極 Taiji). (See Fung 1976) “Cosmology" was based on the theory that the Principle ( $R i$ 理, Chin. $L i)$ and the Material Force ( $G i$ 氣, Chin. $Q i)$ were combined to drive creation and evolution of the universe. The Principle is a formless, motionless metaphysical aspect which refers to value while the Matter (Material Force) is visible and movable which homologizes the conditions in phenomena (physical aspect; fact). (Huang 1999, 131-4) Thus, from the "Cosmology" the Theory of Principle and Material Force constitutes the doctrinal foundation of Neo-Confucianism that sought to explain nature, society, and human beings.

The next foundation is the Theory of Mind and Nature (Simseongron 心性論, Chin. Xinxinglun). It is the application of $R i$ (理) and $G i$ (氣) to Human Mind. Because Heaven endows the whole universe and every part of it with its own nature, there can be harmony in the world, but only if each part acts according to its original nature. Namely, the heart of man is therefore equal to the universal order; it is a reflection of the natural patterns. Accordingly, the Human Mind (Sim 心, Chin. Xin) is consisted of the two following aspects: Nature (Seong 性, Chin. Xin) and Emotions (Jeong 情, Chin. Qing). Here, Nature (Seong) is to R $i$ what Emotions (Jeong) are to $G i$ and both of them syncretize in Human Mind. 
There are two types of Nature, namely: Origina1/Fundamental/Metaphysical Nature (Bonyeonjiseong 本然之性, Chin. Benranzhixing) by Heaven from the beginning of the Universe, and Material/Psychophysical Nature (Gijiliiseong 氣質 之性, Chin. Qizhibixing) (Huang 1999)—it already manifested, expressed, and released one. The former is regarded as perfectly good, while the latter as having had the potential of not being good. (ibid., 131-4) Here, the word Material/Psychophysical temperament (Gijil 氣質, Chin. Qizi) is the condition/bowl/container in which Nature (Seong) is placed. In accordance with the quality of Material Nature, the status of all things or all creation is to be decided. When the Nature is fully-perfect, it becomes to be a human being. If the Nature is leaning or imperfect, it is to be plants, animals, or inanimate things. The variations in physical endowments are due to factors beyond human control.

\begin{tabular}{|c|c|}
\hline Nature $-\square$ & $\begin{array}{l}\text { Original/Fundamental Nature (Bonyeonjiseong 本然之性) } \\
\text { Material/Psychophysical Nature (Gijiliziseong 氣質之性) }\end{array}$ \\
\hline $\begin{array}{l}\text { Material Nature } \\
\text { (Gijijljiseong } \\
\text { 氣質之性) }\end{array}$ & 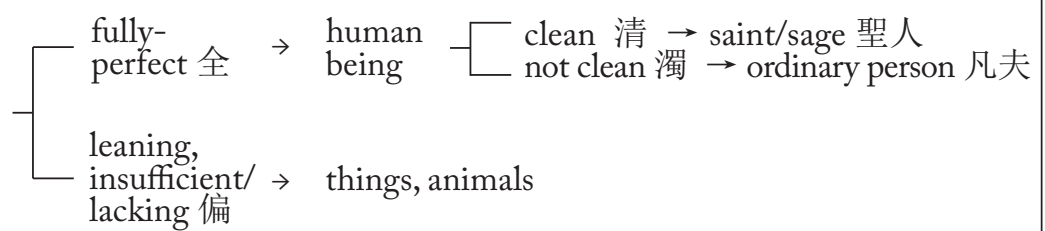 \\
\hline
\end{tabular}

Illustration 1: Nature (性 Seong) (Source: author's own work)

There are two types of Nature. They are: Four Beginnings/Buddings/Germs (Sadan 四端, Chin. Siduan) and Seven Emotions/Feelings (Chiljeong 七情, Chin. Qiqing). It was Mencius who proposed the Four and the Seven, when he argued that human nature is inherently good. He saw that commiseration, shame, modesty, and moral discernment of the human mind and heart are the beginnings of the Four Virtues: Benevolence/Humanity (In 仁, Chin. Ren), Righteousness (Yi 義, Chin. Yi), Propriety/Rituals ( $Y e$ 禮, Chin. Li), and Wisdom ( $i$ 智, Chin. Zhi). The Seven Emotions include Joy ( $H y i$ 喜, Chin. Xi), Anger (No 怒, Chin. Nu), Sadness ( $A e$ 哀, Chin. $A i)$, Fear (Gu 懼, Chin.Ju), Love ( $A e$ 愛, Chin. Ai), Hate/ Repulsion ( $O$ 惡, Chin. $W u$ ), and Desire (Yok 欲, Chin. Yu). Yet, Mencius also considered the Four Beginnings of moral feelings to cause goodness in human nature, (Ching 1985, 304-5) but he did not clearly distinguish such moral feelings in the Four Beginnings from the general feelings in Seven Emotions. 


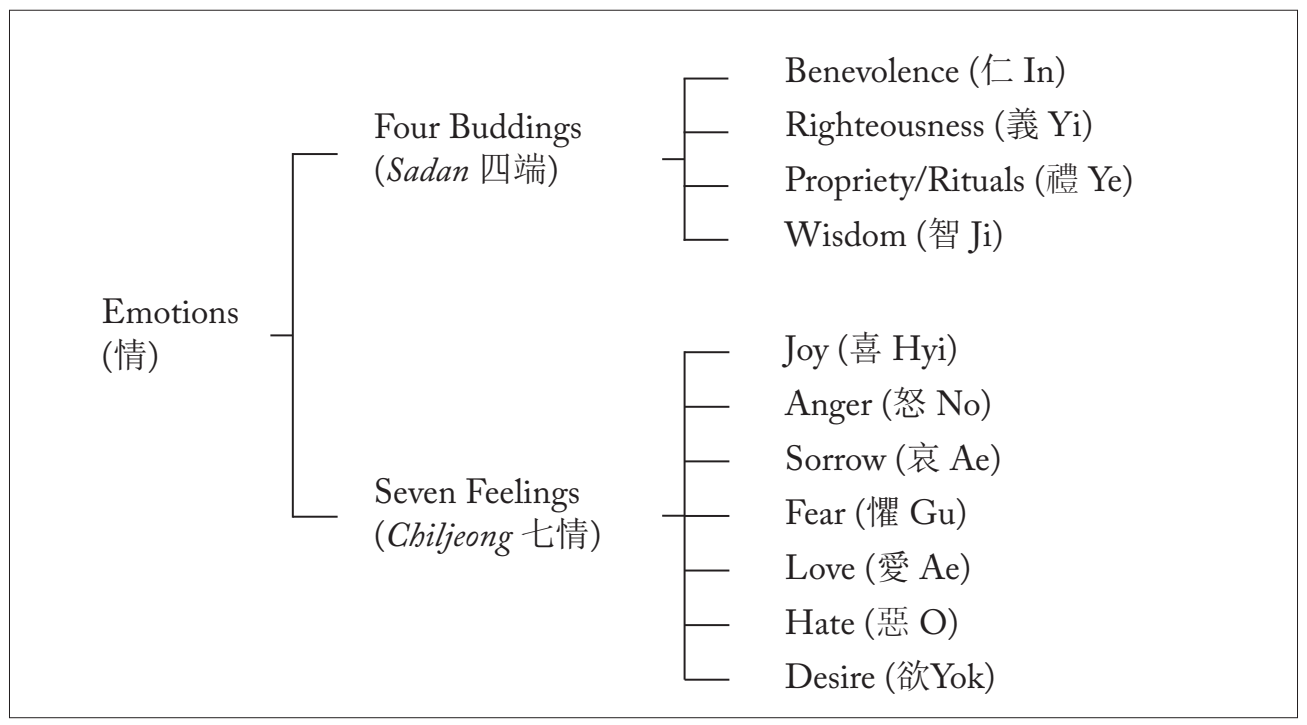

Illustration 2: Emotions (情 Jeong) (Source: author's own work)

It is $\mathrm{Zhu} \mathrm{Xi}$ who actually tried to make a distinction between the Four and the Seven, based on his philosophy of $R i$ and Gi. According to him, the distinction between the Four and the Seven is clear because the Four Beginnings manifest $R i$, while the Seven Emotions manifest $G i$. However, he also perceives an unclear link between the Four and the Seven, as he acknowledges that the Four beginnings also belong to the realm of emotions or feelings. It was the Joseon literati themselves who elaborated and updated the Chinese version much more. The $R i-G i$ relations, which were processed in 16th century Joseon Korea, are important theoretical grounds by which the Four-Seven debates unfolded, the outcomes of which will be discussed further.

\section{Theory of Self-Cultivation}

The theory of self-cultivation is a holistic concept that includes all kinds of human efforts to change themselves into a fulfilled being overcoming their current existential incompleteness. The ultimate object of self-cultivation in $\mathrm{Neo}-\mathrm{Confu}-$ cianism (Zhu Xi's version) is to become a sage by training so as to reach the status of Noble Gentleman status. ZhuXi believes morality exists a priori in the human heart. His view is closely connected to his cosmological views.

There are four ways to practise the theory. The first one is "Staying in quiet reverence (Gyeong 敬) to fathom the heavenly Principle”一居敬窮理 (Geogyeong 
Gungri, Chin. Jujing Qiongi) ${ }^{4}$. Self-cultivation was able to "exhaust" the naturally integrated universal order (Gungri 窮理, Chin. Qiongi), which mostly happened in the form of studying the ancient writings (e.g. Classics). Gyeong is the main principle of self-cultivation. It could be defined as "uniformity", which means the substance in itself. So, "Staying in quiet Reverence" is a method of the inner cultivation of the mind to cultivate one's personality. However, it contains solemn attitude which is expressed outwardly. "Fathoming heavenly Principle" is the method of outer self-cultivation of mind to extend knowledge by studying reasons of all things.

Second, Zhu Xi's fundamental idea of Nature stresses the doctrine of "investigating things and perfecting knowledge (Gyeokmul Chiji 格物致知, Chin. Gerwu Zhizhi)" in which he relates $R i$ to ethics through self-cultivation. Gyeokmul (格 物) means studying deep into the root of matter, while Chiji (致知) is to dig into the heart of a fact to find the correct answer and knowledge. In other words, the way of "investigating things" (Gyeokmul) must be an introspection building on what is already "known" of the Principle $(R i)$ which leads outward to extend one's knowledge (Chiji). (Gardner 2007, 8) In Zhu Xi's view, because moral authority is inherent both in the human mind and in all other things, it is possible to investigate the Principle $(R i)$ not only in the human mind but also in the relation between the self and things.

The third is “moral cultivation and self-reflection (Jonyang Seongchal 存養省察 Cunyang Shengcha)". Jonyang is preserving one's self, in other words, cherishing the nourishment of mind; thus it is the previous state originating from inner mind to preserve and grow the original and natural mind given to men. Seongchal is examining oneself; these are the ways to see and correct the mind. The combination of Jonyang and Seongchal as a moral discipline requires a nourishment and cultivation of the original moral mind when the Principle is hidden and resting, before it becomes manifest and critical of the self when the Principle is moving, having gained Material Force. (Yuksel 2013, 179)

The final methodological approaches of how an ordinary person may become a saint/sage is through "cherishing the heavenly Principle $(R i)$ and denying $\mathrm{Hu}-$ man Desires” (Joncheonri Geoinyok 存天理 去人欲, Chin. Cuntianli Qurenyu). The nature of the heavenly Principle and the essential nature of matter can never be separated, but the former must continuously conquer the latter. Abnormal or excessive life desires are in opposition to the principles of Heaven. This is the Neo-Confucian notion of controlling human desires by the Principles of

4 Or, it is translated as “dwelling in Gyeong" exhausting Ri. Zhu, Xi. 朱子 Zhuzi yulei 朱子語類 (Topically Arranged Conversation of Master Zhu), 1986, 403-4. 
Heaven, as well as preserving the principles of Heaven and removing human desires. (Yu 1992, 308-12)

\section{Theory of Fidelity}

In the book Confucius named "Spring and Autumn (Chunchu 春秋 Chin. Chunqiu) — the history of ancient Lu state" (魯 1048-256 BCE), he instituted the new sacrament of the contract of allegiance called the "Code of Honor" (Daeyimyeongbun 大義名分, Chin. Dayimingfen). This sacrament is therefore often and generally spoken of as the "Great Principle or Code of the Spring and Autumn Annals (Chunchudaeyi 春秋大義, Chin. Chunqiudayi)" and was perceived as the principle of royalty even when the state was collapsing in relation to its historical background.

Neo-Confucianism undertook a hermeneutic shift from the exegesis and annotation of textual particulars to the elucidation of a text's "great significance" (Daeyi 大義, Chin. Dayi) or “moral principles” (Yiri 義理, Chin. Yiyi). This term has been used as the embodiment of righteousness and rational principles. The principles encompasses: 1) The theory of Rectification of Names (Jeongmyeongron 正名論, Chin. Zhengminlun $)^{5}$ - against to injustice and unrighteousness; 2) The Discourse on Revering the King (Jonwangron 尊王論, Chin. Zunwanglun) the kindhearted government (Injeong 仁政) and rule by virtue (Deokchi 德治); 3) A Sinocentric view of civilization and barbarism (Hwairon 華夷論 Chin. Huáyílun) revering Hàn China and expelling the Barbarians; and 4) The idea of Great Unification of the Nations (Daeiltong 大一統思想, Chin. Dayitongsixiang), which calls for the unification of the nations in peaceful coexistence.

\section{Confucian Ritual Formalities}

The Confucian term 禮 (Ye, Chin. $L i)$ is described as all traditional forms that provided a standard of proper conduct. Literally, it means "rites" but it can also be used to refer to "ceremony" or "rules of conduct". Even more, the term has come to generally be associated with "good manner" or the "upright way".

The traditional Confucian understandings of propriety and behavior had been guided by the Three Rites ("Rites of Zhou" (Jurye 周禮, Chin. Zhouli)", the Book of Rites (Yegi 禮記, Chin. Liji), and the Book of Etiquette and Ceremony (Yirye

5 He defined "Let the ruler be a ruler, the minister be a minister, the father be a father and the son be a son". Analects 12: 11 . 
儀禮, Chin. Yili). However, while the first one concerns the bureaucracy and organizational theory rather than "ritual" as commonly understood, the second and the third treat all the criteria of social behaviors and ceremonial rituals. The Book of Rites and the Book of Etiquette and Ceremony are much more concrete and exhibit an effort to control people's external behavior. In Book of Rites, Confucian ceremonial rituals include series of important rites such as the family rites of capping, wedding, burying, mourning, and sacrificing, the village rites of drinking, banqueting and archery, and the state rites of interchanging missions, visiting the emperor, and offering sacrifices to Heaven. Additionally, the Book of Etiquette and Ceremony provides the detailed descriptions of these ceremonial rites. (Fan 2012, 143)

The family rituals developed a lot during the Neo-Confucian revival. The Family Rituals of Master Zhu (Jujagarye 朱子家禮, Chin. Zhuzijiali) was important part of Zhu Xi's effort to strengthen the moral fiber of Chinese society by standardizing major social rites of passage according to his reconstruction of the orthodox Confucian forms and principles. This book is a manual with running commentary of four rituals: capping and pinning (initiation), wedding, funeral, and rituals to ancestral spirits. As its ceremonial ideal, Zhu Xi's Family Rituals presents the "foundation of decorum and eclecticism of scholarship and experience" that were presented as state principles of ancient rituals, and gives top priority to establishing a household shrine system, where ancestral tablets were enshrined and all ceremonial acts were performed. This book had been influential for a long time not only in China, but also in other countries of Confucian civilization-Japan, Korea, and Vietnam.

\section{Theory of Statecraft Idea}

Statecraft Idea (Gyeongseron 經世論, Chin.Jingshilun) is one of four main spheres of Neo-Confucianism. ${ }^{6}$ It includes all the political ways to solve problems in social realities and covers all the theories of management systems for the Neo-Confucian Ideal State. However, the idea was perceived as the ultimate goal from the ancient Confucian thoughts.

The classical principles of the statecraft idea were treated with serious significance. In the Book of Documents (Seogyeong 書經, Chin. Shujing)—one of the Five

6 They are: 1) Theory of Principle and Material Force (Rigiron 理氣論, Chin. Liqilun); 2) Theory of Mind and Nature (Simseongron 心性論, Chin. Xinxinglun); 3) Theory of Self-Cultivation (Suyangron 修養論, Chin. Xiuyanglun); and 4) Theory of Statecraft Idea (Gyeongseron 經世論, Chin. Jingshilun). 
Classics of ancient Chinese literature-the sage ruler's governing principles and models are suggested, and especially, systemized in practical assignments of nine categories in the chapter of the Great Plan (Hongbeom 洪範, Chin. Hongfan). Namely, being founded on the Mandate of Heaven (Cheoxnmyeong 天命, Chin. Tianming) and the Governing by virtue (Deokchi 德治, Chin. Dezhi), the book proclaims the Confucian ideal of the type and origin of statecraft presenting political assignments such as the institutions, the law, production, material goods, rituals, and astronomy in a concrete form.

Confucius also showed his willingness to establish political order in place of the chaos at the end of the Spring and Autumn Period and set up the political ideology of the Governing by virtue and the Governing by propriety (Yechi 禮治, Chin. Lizhi). In the same context, Mencius developed statecraft idea in his Righteous Kingly Way Politics (Wangdo Jeongchi 王道政治, Chin. Wangdao Zhengzhi) pursuing the realization of his political idea on the basis of public welfare and stability in economic spheres such as tax reform and the land reform.

$\mathrm{Zhu} \mathrm{Xi}$ also laid stress on land reform and developed Mencius' idea that the WellField System (Jeongjeonje 井田制, Chin. Jingtianzhi) was to be the foundation of benevolent governance. His ideal was the realization of a society under benevolent leadership, through which all people live comfortably with "constant minds" (恒 心, Chin. Hengxin) by "constant production” (恒産, Chin. Hengchan). That was why the Great Learning (Daehak 大學, Chin. Daxue) became a classic in the statecraft learning of the Chinese emperor when Zhu Xi first presented it to the throne in the Southern Song court.

\section{Main Issues of Joseon Neo-Confucianism}

The NeoConfucian vision of the world as a moral whole, in which the scholar had the most privileged position by access to the Confucian classics, became the basis for literally all formal state systems. Moreover, Zhu Xi's thought was the basis for Korean scientific discourse and this system of knowledge was more advanced in many fields than its rivals in the West until the 17th century. However, it is true that majority of the scholars-lost in the abstractions of too "fuzzy" discourses on "virtue" and "filial piety" — used NeoConfucian learning as a dogmatic ideology to justify their rule and to reject the modernization of the country. Furthermore, differences in the factional disputes over propriety reflected conflicting views of medieval Korea's social systems and were to be undertaken as part of an inevitable process amid changing social systems in the late Joseon period. 


\section{Debates on "Four-Seven"}

Joseon Neo-Confucianism is an upgraded version of the Chinese original. It contains much more elaborated consideration on human emotions. Neo-Confucianism, which is mainly based on the Principle and the Material Force, has difficulty maintaining the balance between $R i$ and $G i$, for it is usually inclined toward either $R i$ or $G i$ domination. The debates are the very matter of moral judgment and ethical behavior for the Joseon Neo-Confucian scholars' philosophical subject and was vigorously proceeded for a long time.

The theoretical instrument of the analysis was the Four Beginnings (Sadan 四 端, Chin. Siduān) and the Seven Emotions (Chiljeong 七情, Chin. Qiqing). Thus, the Four-Seven Debate (Sadan-Chiljeong) dealing with human moral emotion as a philosophical subject includes the matter of human nature, mind, and emotion. Among the debates, the most famous ones were between Yi Hwang (李滉 1551-1570) and Ki Daeseung (奇大升 1527-1672) in 1559-1566 and between their disciples-Seong Hon (成渾 1535-1598) and Yi Yi (李珥 1537-1584) in 1872-1578.

Yi Hwang and Seong Hon are the representative scholars of the theory of the Principle's $(R i)$ dominance (Juriron 主理論, Chin. Zhulilun). On the theory of the Principle and the Material Force (Rigiron 理氣論, Chin. Ligilun), Yi Hwang's first thesis was the one of "Mutual Issuance of Principle and Material Force" (理 氣互發 Rigihobal). According to him, " $R i$ is noble; $G i$ is mean" (Rigui Gicheon 理 貴氣賤). $R i$ stands for pure virtue, because it is absolutely good virtue from the Heaven. On the other hand, Givaries. It may be good or bad because of its human aspects. (Yi 1985, 416) Here, he applied his opinion on $R i$ and $G i$ to the "Theory of Mind and Nature" (Simseongron 心性論). Thus, the Principle is Nature, while Matter is Emotions. This scheme shows his core conception on Four Buddings and Seven Emotions.

Furthermore, Yi Hwang elaborated his conception on the Four Beginnings and Seven Emotions following four theses: (Yi 1985, 402-4)

1) “Four Buddings are manifested from $R i$, therefore, purely good” (四端之發 純善故無不善);

2) "Seven Emotions are manifested from $G i$ and, accordingly, can be either good or evil” (七情之發 兼氣故有 善惡);

3) “Four Buddings are manifested from $R i$ and $G i$, thus passively follow it"; (四 端理發而氣隨之);

4) "Seven Emotions are manifested from $G i$ and $R i$, therefore, passively rides on (accompanies) it”. (七情氣發而理乘之)”. 
Yi Hwang regarded both the Four Beginnings and Seven Emotions as the same "emotions", but distinguished one from another considering their origins and functions. The scheme 3 shows his core concept on "Four-Seven" based on Ris domination (Juriron 主理論, Chin. Zhulilun).

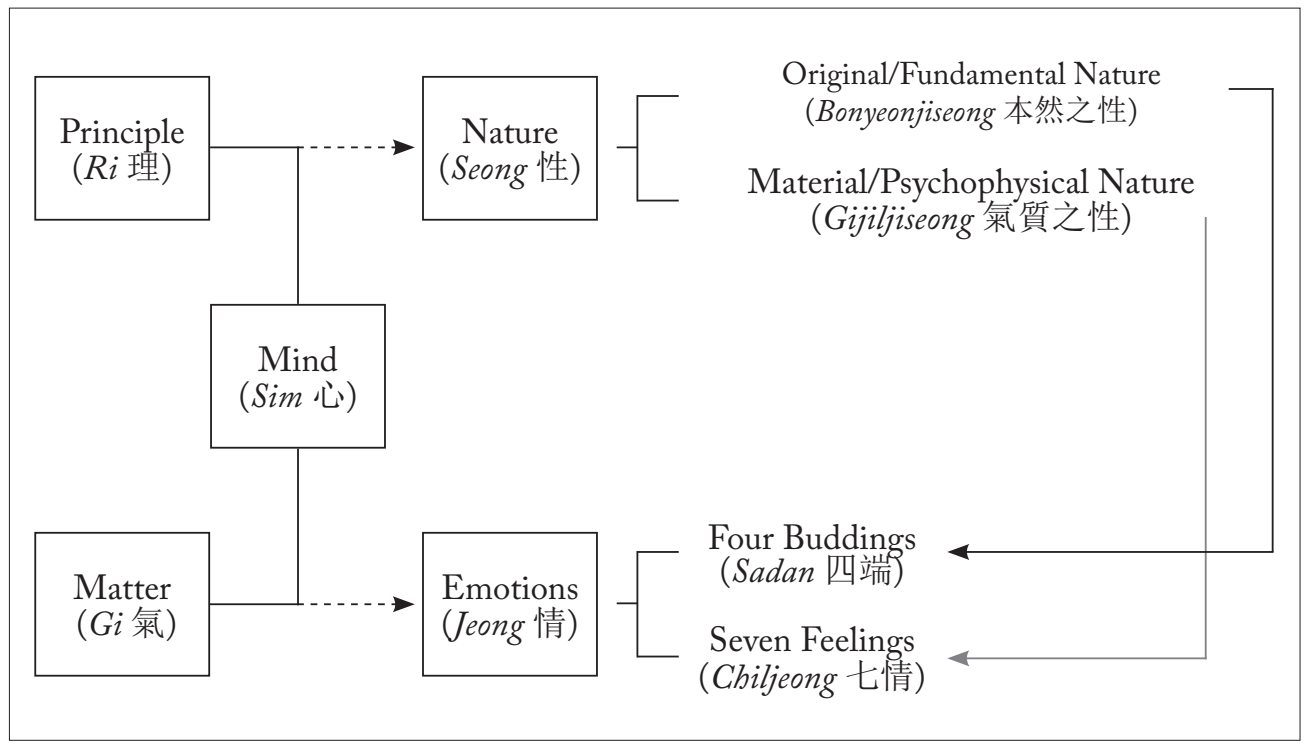

Illustration 3: Yi Hrwang's conception on Ri's dominace and "Four-Seven". (Source: author's own work)

Whereas Yi Hwang considered the Principle to be much more important than Matter, Yi Yi stressed that both $R i$ and $G i$ are significant. He could not accept $Y i$ Hwang's view of the dominance of $R i$, therefore he denied it. Yi Yi thought it meaningless to define some kind of superiority between them.

For $\mathrm{Yi} Y \mathrm{i}$, the notion that everything is dependent was considered a given fact. $\mathrm{Yi}$ $\mathrm{Yi}$ constructed the theme of " $R i$ openly penetrating in all aspects, and $G i$ being confined in space and time (Ritongiguk 理通氣局)”.(Yi 1988, 44: 210d-211a) In accordance with this point, his interpretation is that "when there's one $R i$, there's also one $G i$. Likewise, when $R i$ becomes divided into ten thousand parts, there are tens of thousands of $G i$." Because there is "Indescribably wonderful relation between and Gi (Rigijimyo 理氣之妙)” which makes them mixed in Harmony. (ibid., 10: 201-3) 


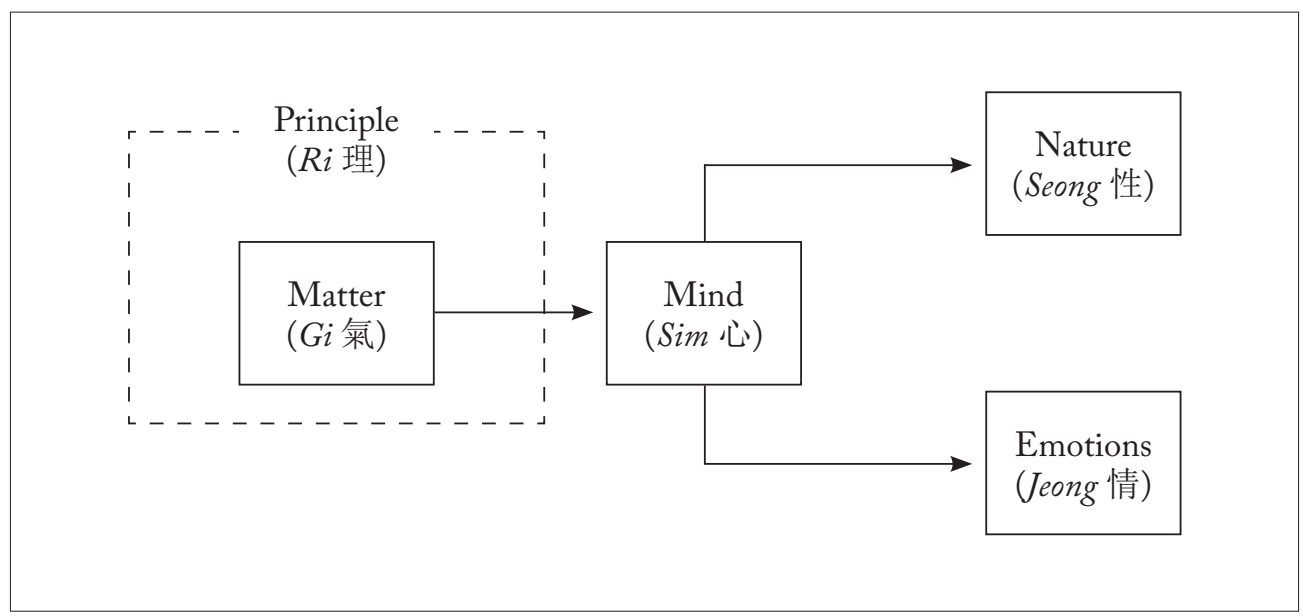

Illustration 4: Yi Yi's conception on Gi's dominance. (Source: author's own work)

The Four Beginnings are all human feelings. In his view, $R i$ is just a principle. What exists in reality is $G i$. Human nature or emotions, all of them come from $G i ; R i$ is the Principle which drives $G i$. Likewise, Yi Yi transformed dualistic theory of human nature ( $R i$ and $G i)$ into the monistic theory. In other words, he understood human nature as holistic and balanced ways. In that context, he elaborated on his version of “Theory of Gis Dominance (Jugiron 主氣論, Chin. Zhuqilun)".

$\mathrm{Yi} Y \mathrm{i}$ thought much of the unity that $R i$ and $G i$ are not separable. He claims that " $R i$ is non-active, and $G i$ is active; $G i$ issues and $R i$ mounts it as one does a horse (Gibalriseung 氣發理乘)”. (Yi 1988, 10: 26a) In other words, $R i$ as the Principle, riding on manifested Gi, Ri drives/controls it. For him, the Four Beginnings are selected good parts of the Seven Emotions and they are connoted in the Seven Emotions. Thus, Yi Yi's view on "Four-Seven" of "Gi's dominance (Jugiron)" can be summarized as "the Four Beginnings are purely good in $G i$; the Seven Emotions also are in $G i$ which could be either good or evil. That is why the Four Beginnings are a purely good part of Seven Emotions in $\mathrm{Gi}^{7}$.

$7 \quad$ For more details, see Han1996, 111-4. 


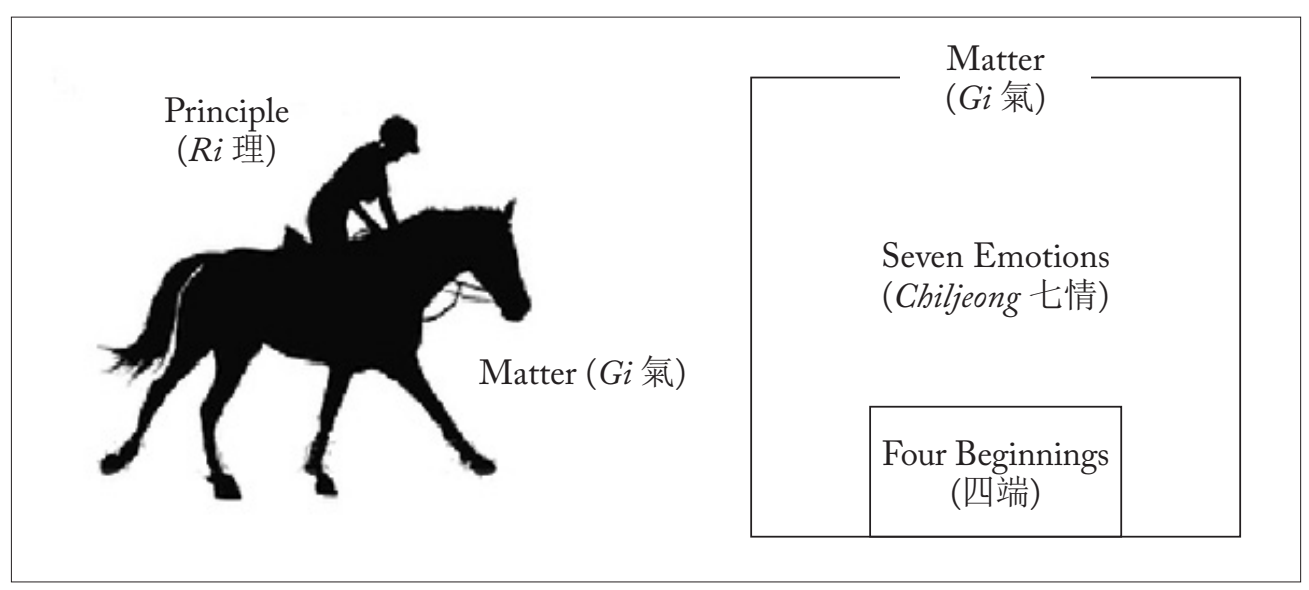

Figure 3: Yi Yis Gibalriseung and Four Beginnings' place. (Source: author's own work)

According to Jeong Yakyong, different points of view between Yi Hwang and Yi $\mathrm{Yi}$ were caused by the divergence of methodological approach to the conceptualization of $R i$ and $G i$. Yi Whang built up these concepts from the nature of human being Inductive while Yi Yi created them from summarization of all the creations in the world Deductive. ${ }^{8}$

\section{The Historic Processes of Fidelity}

The spirit of the Righteousness (Yiri 義理, Chin. Yili), which highly respects the Moral Code (Gangsang 綱常, Chin. Gangchang) and Fidelity (Jeolyi 節義, Chin. Jieyi), to classical Confucian principles was the core standard in the Joseon dynasty's understanding of Neo-Confucianism.

Sarim (士林) literally means "forest of scholars" or the "scholars in the rural district", namely the term implies the "literati out of state office". Such a group of Neo-Confucian scholars emerged with the establishment of the Joseon dynasty. Though a majority of the scholars had very negative attitudes toward the society of Goryeo - the former dynasty (918-1392), Sarimpa was fraction that rejected to serve the new dynasty and criticized the immorality of the ruling party called Hungupa. (勳舊派) 一 the Meritorious Power group-in the new dynasty.

Though they were opposite to the new Joseon dynasty, ironically Neo-Confucian state ideology highly acknowledged their loyalty to Goryeo because of their

$8 \quad$ For more details, see Lee 1987, 381-4. 
Confucian teaching that “A loyal subject never serves two kings (忠臣不事二主)”. That was Sarim's spirit of the Righteousness.

Later, such a strong belief of Righteousness was revealed again during the King Sejo's reign (1455-1468). Apart from the major groups of Sarim and Hungu Factions, there were also some minor groups in the early Joseon dynasty. They were Jeolyi Faction (Jeolyipa 節義派). The Sarimpa regarded that King Sejo, who was tainted by the usurpation of his nephew's throne, impaired the Neo-Confucian morality and righteousness and denied to serve King Sejo against the injustice of breaking legitimacy. The Jeolyi Faction was the group of people who committed to fidelity against King Sejo's "unfair accession" to the throne, such as the "Six martyred ministers" (Sayuksin 死六臣), who had been killed by the new power group. Afterwards, the historical reputation had strongly leaned to the side of the resisters for their spirit of Fidelity. The pair of $Y i$ (Righteousness 義) and $L i$ (Principle 理) was a central proposition for the Korean Neo-Confucian scholars. They often clashed with the interests of the privileged strata and eventually suffered a series of literati purges (Sabwa 士禍). ${ }^{9}$

Next to the fidelity of the scholars toward the "legitimate" throne, the "Righteous Army" (Yibyeong 義兵), which means volunteer corps, their regard for the righteous spirit is worth mentioning. The emergence of the "Righteous Army", led mainly by Neo-Confucian scholars, occurred over three phases in the Joseon dynasty. The first one rose up during the Japanese invasions of Korea (1592-1598). The volunteer corps were organized in the cause of justice to resist Japanese invaders and to keep Joseon dynasty with loyalty and righteousness. These volunteer corps were also organized during the long period of Japanese invasion and occupation from 1890 to $1945 .{ }^{10}$ These movements were initiated by the Neo-Confucian scholars under the slogan of "Defending Orthodoxy and Resisting Heterodoxy" (Wijeong Cheoksa 衛正斥邪), ${ }^{11}$ but later comprised the disbanded Korean imperial guard as well as farmers forming over 60 successive righteous armies to fight for Korean self-reliance and independence. ${ }^{12}$ It became the whole nation's resistance against

$9 \quad$ There were four literati purges during the Joseon dynasty. They are: the First Literati Purge (Muosab$w a$ 戊午士禍) in 1498; Second Literati Purge (Gapjasahwa 甲子士禍) in 1504; Third Literati Purge (Gimyosahwa 已卯士禍) in 1519; and Fourth Literati Purge (Eulsasahwa 乙已士禍) in 1545.

10 Some Korean historians define the period in 1895-1910 as the "War of Righteous Armies Period (義兵戰爭期)”.

11 However, this theory implied the Sino-centric ideology and applied it to the social situation. In other words, this kind of view in the second half of 19th century Joseon dynasty devoted all its energies to build up Yiriron into social ideology. Such as it was, it was quite exclusive and easily fell into conservative closed-mindedness.

12 The most famous uprisings were: the Righteous army of Eulmi (Eulmi Yibyeong 乙未義兵) in 1895, Righteous army of Eulsa (Eulsa Yibyeong 乙巳義兵) in 1905, Righteous army of Jeongmi (Jeongmi Yibyeong 丁未義兵) in 1907 and Thirteen Province Alliance Righteous Army (Sibsmado Changyigun十三道倡義軍) in 1908. 
Japanese unrighteousness. Such a tradition of righteous sprit was continued in the form of a national armed struggle against Japanese imperialism during the occupation period (1910-1945).

The spirit of the Righteousness (Yiri) implies a somewhat different view in the frame of traditional East Asian political order. China was the center of "All Under Heaven" as a territory and capital region ruled directly by the Son of Heaven (Cheonja 天子, Chin. Tianzi; the Emperor), however this concept referred only to Han (漢 Chin. Han) Chinese dynasties. Neither Khitan Liao (遼; 916-1125), nor Mongolian Yuan (元 Yuan; 1260-1368), nor Manchurian Qing (清 Qing; 16361912) were considered as the "real" Chinese-thus Confucian-dynasties. Accordingly, during the Joseon dynasty, the Sino-centric vision of the world (Hwairon 華夷論) was deeply rooted among the neo-Confucian scholars. ${ }^{13}$ Moreover, such point of view was widely spread among Joseon scholars after the Second Manchurian (Qing dynasty) invasion (Byeongjahoran 丙子胡亂 1636-1637) in the 17th and 18th century, even though the Han Chinese Ming (明) already collapsed in 1644 . They strove to sustain the identity of Joseon as the protector of genuine Confucian culture and tradition, and felt confident that Joseon was the very state that succeeded Sino-centrism: Joseon as a smaller, but the only post-Sino-centric state (Sojunghwa 小中華).

At the end of the Manchurian invasion, King Injo (1623-1649) was humiliated to bend his knee before Hong Taiji-the emperor of the Manchurian Qing dynasty - had to become his vassal. Before the capitulation, there were two groups of Korean officials in opposition view to each other: Juwharon (pro-reconciliation 主 和論) vs Jujeonron (anti-reconciliation 主戰論 or Cheokwharon 斥和論). Juwharon was the utilitarian view of capitulation to reconcile for the safeguard of the nation and the people sitting down quietly after humiliation, whereas Jujeonron was intransigent in persistence and the king and all the officials had to fight to death. King Injo rather supported anti-reconciliation group presenting strong attitude to fight, ${ }^{14}$ but he changed his mind at the last moment because of the absolute inferiority of his military power.

13 Among modern Korean historians, the Sino-centric vision of the world often was criticized as a blind view following just the Hàn Chinese tradition (Mowhasasang 慕華思想) or submission to the stronger (Sadaejuyi 事大主義). However, it was the most important norm of the principle of Confucian righteousness (Yiriron) in traditional society, led by the Sino-centrism as well as Neo-Confucian ideology in Joseon.

14 "What I really want to keep is Great Righteousness. No matter the consequence of it-whether to succeed, to continue to exist, or to be ruined. If all of vassals and ordinary people, one and all, agree with me, there are only a few days left for you to see your country's collapse." (Songjadaejeon vol. 213, Chapter of Three anti-reconciliation gentlemen) 
Kim Sangheon, one of the "three anti-reconciliation gentlemen" (Cheokwha Samhaksa 斥和三學士), also composed a poem in prison in Shěnyán to express his firm belief that "the matter of success or failure depends on the will of Heaven. However, I abide the issue following the Righteousness." (Keum 2002, 137) That was the real faith of Yiriron, whose attitude is determined by the Righteousness, regardless of any kind of success, failure, profit, or loss.

After the war, the Joseon Neo-Confucian scholars had absolutely espoused the "righteous doctrine" of "Enhancing Ming and Rejecting Qing (Sungmyeong Baecheong 崇明排淸), which excludes the Qing dynasty as the "Manchurian barbarians" and respected the already ruined Ming dynasty as the only Chinese orthodoxy. Namely, the slogan of "revering China and expelling the barbarians" (Jonjunghwa Yangijeok 尊中華攘夷狄) was regarded as the great truth of Yirion in those times. Such an attitude of Confucius's critical spirit of Great Righteousness (Chunchuyiri 春秋義理) was deeply recognized among the Korean Neo-Confucianists.

In that context, the Qing imperial calendar was not adopted in Joseon, though the dynasty dominated mainland China. Instead the "Sungjeong" (崇禎, Chin. Chóngzhèn) - that of final emperor Yizong's of Ming dynasty (1368-1644)--was widely used in everyday life in all records. The reasons for the collapsed Ming dynasty being revered were: 1) that Ming was the very orthodox dynasty of Han China and to repay a debt of gratitutde to Ming's emperor Shenzong, who helped Joseon "escape a peripheral country from the crisis" (Jaejobeonbang, Chin. 再造藩邦) during the Japanese invasions; and - getting below the surface-2) to accentuate the faith that Joseon did not want to serve Qing, which dominated the mainland of China at that time because of the barbaric Manchurian culture. (ibid., 138)

Moreover, showing his faith on Great Righteousness, the next King Hyojong (1649-1659) was persistent with his goal of a "Northern Expedition" (Bukbeolron 北伐論)—the plan of Military Expedition to Qing dynasty—all the time during his reign to overcome humiliation from the Second Manchurian invasion in 1637.

\section{The Horak Debates on Nature}

Since the early 18th century, the “Horak debate (Horaknonjaeng 湖洛論爭)” arose in the early decades of the eighteenth century and facilitated the comprehensive understanding of $\mathrm{Neo}-\mathrm{Confucianism}$ and reflected social and political situations. A Horak debate is a philosophical discussion transformed Chinese Neo-Confucianism into the peculiar aspect of Joseon's Neo-Confucianism and developed it further. In the word "Horak", "Ho" means Hoseo, which is a region below Seoul, 
and "Rak" which is Seoul and its vicinity. So these are the debates between the scholars based in those two regions.

The root of the Horak debates can be traced back to Yi Yi. He disagreed with Yi Hwang's "unorthodox" conferral of an independent dynamism to a pattern and developed Zhu Xi's interdependent substance-function construction of the pattern - the psycho-physical relation of energy to the pinnacle of logical and systematic coherence. (Lee 2014,142-3) Korean philosophers sought to be liberated from the quintessential search for tangible desires that are the inevitable plague of humankind, in achieving morality that overlaps the bounds of human nature. Yi Yi referred to the natural state of human desire as Gi, or Gijil (氣質 psychophysical conditioning) as essential energy and argued that humans are, from the outset, imbued with a morally pure essential energy. ${ }^{15}$ However, he acknowledges the reality that humans do not solely possess pure essential energy. Subsequently, he emphasized the need to constantly strive for the transformation of other various kinds of essential energy in order to restore one's original, pure heart.

The main issue of the Horak debates is "Sameness-Difference of Human Nature and Material Nature (Inmulseong Dongiron 人物性同異論)”. Here, the material nature means everything of a non-human nature including animals. It was the matter of Nature to examine the substance of Mind (Sim 心). Hence, those debates were provided to define the precise concept of Nature, as well as the prerequisite for understanding the Emotions' phenomena. However, the debates also have additional sub-issues such as the "un-awakened mind itself" (Mibalsimche 未發心體), which means the essential substance, and "the differences of mind between the sage and ordinary people” (Seongbeomsim 聖凡心).

There is a stand-point that defines debates as universal, not particular ones in Korean Neo-Confucianism. On the other hand, there is a methodological contrast. I would like to briefly present two mutually opposite views of the Horak debate representatives: Li Gan (1677-1727) and Han Wonjin (1682-1751).

Li Gan insisted that though the "Nature" (Seong) of "Supreme Ultimate" (Taegeuk 太極), “Mandate of Heaven" (Cheonmyoung 天命) and virtues may be situated at the different places, they are in accordance with each other in essence (substance). For him, the "substance of Mind before its emanation is originally good (Simche

15 Yi Yi's thinking was focused on the theory of self-cultivation in Confucianism, which has the purpose of perfecting humans to a higher state. Therefore, he was less interested in whether the nature of men and animals were the same. Rather, he focused on pointing out the basic goodness of all humans through the theory of " $R i$-through and $G i$-within" or "Pattern pervades, psychophysical energy delimits” (Yi 1988, 3: 10.25a, 32) 
Bonseonron 心體本善論)”. ${ }^{16}$ Thus, he stands for the position that "Nature is $R i$ ” (Seongjeukri 性郎理).Rakron is to Ris dominance and deduction what Horon is to Gis dominance and induction. The followers of Rakron criticize that Horon falls too much into analysis and loses its consistency. As a result, Rakron often misses the relation between the substance and phenomenon.

\section{"Sameness-Difference of Human nature and Material Nature" (Inmulseong Dongiron 人物性同異論)}

- Rakron: Sammenes

- $\quad$ Li Gan (1677-1727)

- $\quad$ Seong (Nature) is $R i$ (Principle)《(性師理)

- $\quad \rightarrow$ Theory of "Profitable Usage and Benefiting the People"

- (Iyonghusaengron 利用厚生論)
- Horon: Differences

- Han Wonjin (1682-1751)

- $\quad$ Seong (Nature) is $G i$ (Matter)《(性師氣)

- $\quad \rightarrow$ Theory of "Defending Orthodoxy and Resisting Heterodoxy"

- (Wijeongcheoksaron 衛正斥邪論)

Illustration 4: Two opposed views on the "Sameness-Difference of Human Nature and Material Nature" (Source: author's own work)

On the contrary, Han Wonjin was on the "Difference of Human Nature and Material Nature" (Inmulseong Sangiron 人物性相異論) and the “substance of Mind before its emanation contains both good and evil (Simche Yuseonakron 心體有善 惡論)". (Kim 2009) However, he doubted “when it comes to Ri (Principle) how the other things could be obtained perfectly in every virtue like a human being?" That is to say, he affirmed that other things were born with partly limited $G i$, while the human being has them perfectly in the nature of temperaments (qualified Gi). Thus, he stands for the position that "Nature is Gi" (Seongjeulgi 性節 氣). Horon saw that Rakron put the first consideration too much in abstraction as to be caught in an empty theory. Besides, the point of Horon on the issue shows affirmative view in the condition of concrete scholars and empiric objects.

Although the Horak discourse was the subject of debate that, at times, rendered its expression in extreme terms, the discourse does not, to a large extent, diverge from Yi Yi's conception. This may be attributed to the broad spectrum of essential energy encompassed by Yi Yi's proposal that various kinds of natural tendencies should be transformed so as to achieve the practice of pure morality. However, the Horak theory may be distinguished from Yi Yi's in terms of the rationale it

16 For further information see Kim 2009, 151-83. 
proposes for the inability to narrow the breadth of this essential energy.

In fact, these debates are historically based on the East Asian international order of those times: the collapse of the Sino-centric Ming dynasty and the reinforcement of the Manchurian Qing dynasty (which the Korean Neo-Confucianists did not want to accept, considering their view of the Qing dynasty as barbarians). Simultaneously, it is the intensification of the Mind and Nature theory (Simseongron 心性論) as well. Later, Horon became basis of the conservative exclusionist power theory “defending orthodoxy and resisting heterodoxy" (Wijeongcheoksaron 衛正 斥邪論); and Rakron became the theory "north learning” which stresses "profitable usage” (Riyong 利用) and “benefiting the people” (Husaeng 厚生). The idea preceded the morality of proper virtue.

\section{Fiery Debates and Conflicts over Ceremonial Protocol Issues}

After the Japanese invasions of Korea (1592-1598) the reinforcement of Confucian ideology was introduced as one of the methods of overcoming the post bellum effects and stabilizing society. The rituals provided a social system people could relate to, and further was a cultural form that justified the discrimination of status, and was a method of education that realized social ideas. The studies on the "Confucian Rituals (Yehak 禮學)" began flourishing fully, so as to form "the Faction of Confucian Ritual Formalities”(Yehakpa 禮學派). Bibliographical study of the ritual formalities (Yegyeong 禮敬) and management of the society accordingly with the norm system by its ritual practice of the Confucian ruling class and official dynasty regulations of state rituals became the most important object of Yehak. Accordingly, from the 17th century, various writings on systematization of "Family Rituals" (Garye 家禮) ${ }^{17}$ emerged. Their studies focused mainly on collecting and investigation of the ritual commentaries to find a concrete system and procedure in accordance with the "Family Rituals of Master Zhu" (Jujagarye 朱子家禮, Chin. Zhuzijiāli), which were comprised of the "Four Rituals"-the Celebration of One's Coming-of-Age; Marriage Ceremony; Funeral Rites; and Sacrificial Rituals. Under the circumstance, the "controversy of fiery debates and conflicts over ceremonial protocol issues” (Yesong 禮訟) were broken up for few times, which was connected with the Faction's interests.

17 For example there were published: “Guide to Family Rituals (Garyejipram 家禮輯覽)”, “Preparing Funeral Rituals (Sangryebiyo 衰禮備要)”, “Explanation to doubtful points on Formalities (Yiryemunhae 疑禮問解)”, “Questions and Answers to State Rituals (Jeonryemundab 典禮問答)”, “Differences and Similarities in Funeral Rites of the Past and Present (Gogeum Sangrye Idongyi 古今 喪禮異同議)", and “Sequel to the Explanation to doubtful points on Formalities (Yiryemunhaesok chin. 疑禮問解續)”. 
Yesong was the most significant issue in politics (under the name of Confucian order) in Joseon Korea. The most heated debate among the Yehak scholars was between Youngnam and Giho Schools on the issue of how the dowager Queen Jo - the former King Injo's second wife- had to wear funeral garment according to the Confucian form of funeral when King Hyojong (1649-1659) died in 1659. This debate originated from the difference of opinion of King Hyojong's status as the former king's son. ${ }^{18}$

\section{How long the dowager Queen should wear mourning for the king her step-son?}

- Song Siyeol (1607-1689)

- Queen dowager 1 year's mourning
- Yun Hyu (1617-1680)

- Queen dowager 3 year's mourning

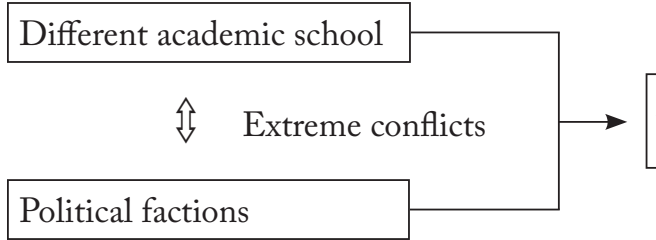

Academic genealogies in the real politics, with the faction strife

Illustration 5: Gibae Yesong in 1659 (Source: author's own work)

Song Siyeol and Song Jungil of Giho School insisted that the Queen dowager should go into mourning for 1 year, while Yun Hyu and Heo Mok of Youngnam School insisted on mourning for 3 years. In consequence, the final decision was up to the style of dress during a one year period of mourning. However, this fiery debate and conflict over the ceremonial protocol was repeated as political confrontations and continued to be the struggle for political hegemony for 35 years. Though Hyojong was the second son, he ascended to the throne because of the Crown Prince Sohyeon's death. When it comes to the succession to the throne, it

18 King Injo (1623-1649) had two sons--the princess Sohyeon and Bongrim. Their mother died in 1636 and king Injo married again in 1638. His second wife, later known as Queen Changneol, was a teenage member of the Jo family. She bore no sons. In 1645 Sohyeon, the Crown Prince, died. When King Injo died in 1649, his younger son, Prince Bongrim, later known as King Hyojong, came to the throne. His step-mother, Queen Changneol, was then 25 years old and became dowager Queen Jo (Jodaebi). Ten years later, when King Hyojong died, there was a question as to how long the dowager Queen should wear mourning for King Hyojong, her stepson. This conflict arose because there was no previous record about Confucian funeral requirements when somebody's second stepson who actually succeeded the family line dies. 
was always regarded that the eldest prince should be the "Proper Line of Descent" (Jeoktong 嫡統) in the Joseon dynasty. In other words, not every prince by blood has equal qualifications for succession. On the other hand, however, the one who already succeeded to the throne-though he was not the eldest prince-had the "Legitimate Line of Descent" (Daetong 大統), which was relevant to Jeoktong. The criterion-which of them had to adapt: whether Daetong comprises Jeoktong, or Jeoktong as the foundation of Daetong - is very significant to understand the royal authority. It is also important to define social order of the dynasty. The mission of Yesong in the second half of 17th century was to explain the theoretic system of Yehak logically as well as to raise Yiriron in the Yehak style. It is true that Yesong functioned as the main factor of extreme conflict and schism in real politics with the factional strife. However, Yehak was continuously developed, even after the Yesong debates in Neo-Confucian Joseon.

\section{Statecraft Ideas}

There were a lot of Statecraft (Gyeongseron 經世論) theorists in Joseon. Almost every Neo-Confucian scholar presented his own version of the theory. In this article, the most prominent scholars' ideas will be announced.

Jeong Dojeon (1342-1398), who played a leading role in founding the Joseon dynasty and mapping out its ruling institutions, authored "On Mind, Material Force, and Principle" (Simgiiripyeon 心氣理篇) and “An Array of Critiques against Buddhism” (Bulssi japbyeon 佛氏雜變) to refute Buddhism and Taoism. ${ }^{19}$ In these books, he expounded Neo-Confucian theories, ranging from the cosmos to the governance of human beings and the state. He defined the most important goal of statecraft; that is Humane Governance (Injeong 仁政) based on Demo-centric idea (Minbon 民本) and Ruling by Virtue (Deokchi 德治). His statecraft idea was systemized into “Administrative Code of Joseon (Joseon Gyeongukjeon 朝鮮經國 典)" and “Mirror of Governance (Gyeongjemungam, Chin. 經濟文鑑)”.

In the Joseon Gyeonggukjeon (朝鮮經國典), the duties of each organ were defined in the Six Codes of Law. ${ }^{20} \mathrm{He}$ evidently clarified the Demo-centrism as

19 Jeong strongly addressed his points as follow: 1) the Buddhist ideas of samsara and karma are wrong and immoral; 2) the Buddhist theory of knowledge neglects objective principles of the phenomenal world as only an "illusion"; and 3) the Buddhist method of self-cultivation is focused too much on the "emptiness" of the mind, ignoring the family and society. See Keum 2007, 98-136.

20 They are: “Governance” (Chijeon 治典), “Taxation” (Bujeon 賦典), “Rite” (Yejeon 禮典), “Administration” (Jeongjeon 政典), “Law” (Heonjeon 憲典), and “Manufacturing” (Gongjeon 工典). 
the core idea of the governing Joseon dynasty saying “... On the whole, the ruler relies on the nation, and the nation on its people. The people are the foundation of the nation, of Heaven and of the ruler...". Furthermore, the next thesis, that "...The people are weak but cannot be threatened with might, and they are foolish but cannot be fooled by cleverness...", represents the idea that political power over people must be under restriction. Likewise, he firmly settled the Democentric and Virtue-Governance ideas to be an essential ruling ideology saying "a ruler's position must be maintained through Virtue, so as to gain the people's heart”.

While the "Administrative Code of Joseon" is mainly about the governing systems with its "Governing a Nation and Relieving the Subjects" (Gyeongse Jemin 經世 濟民), “Mirror of Governance" emphasizes the honorable attitudes and responsibilities of government officials. This writing explains the history of the premier system, the duties of the premiers, the attitude towards resigning or remaining in the function of premier, the duties of remonstrators, guard officers, provincial governors, and county chiefs in due order.

Jo Gwangjo (1482-1520) was the first scholar who returned to political reality from the Sarim Faction. He mentioned the king's basic duties during the royal lectures: 1) respect the real (orthodox) Confucian studies (Sungjeonghak 崇正 學); 2) straighten people's minds (Jeonginsim 正人心); 3) pattern oneself after former wise and holy men (Beobseonghyeon 法聖賢); and 4) set up ideal politics (Heungjichi 興至治). ${ }^{21} \mathrm{He}$ was of the opinion that a ruler's mind must be under the control of scholars who are acquainted with the Neo-Confucian ideal. Thus, the Confucian gentlemen as well as the men of virtue (Daein 大人, Chin. Dàren) are to support a ruler and a ruler must trust them to distinguish proper personnel from inferior ones to create ideal politics in which the state remains at peace with people under protection. By Jo's own account, the realization of the ideal politics (Jichi 至治, Chin. Zhizhi) must be accomplished by gentlemen who are Confucian scholars. (Jo 1988, 22: 145-50)

Li Eonjeok's (1491-1553) commentary on the "Nine Classic Epigrams of Doctrine of the Mean" (Jungyong Gugyeong Yeonyi 中庸九經衍儀) is his unfinished work of unique and extensive research on the "Doctrine of the Mean" (Jungyong 中庸, Chin. Zhongyong). Li systemized ruling principles and methods adapting the nine epigrams in chapter 20 of the "Great Learning" (Daebak 大學, Daxue) - which are the basic subjects of governing a country-into the structure of

21 Yi Yi, “道峰書院記 (The Records of Dobong Confucian Academy)” and “經筵日記 (Diary of the Royal Lectures).” In 율곡전서 (Yulgokjeonseo: Complete Book of Yulgok's Works). Vol. 13, 28. 1988. 
the book..$^{22}$ This book has great meaning of profound study on the classical texts of Confucianism as well as the statecraft ideas of Neo-Confucianism.

Further, the “One Principle of Ten Provisions” (Ilgang Sibmokso 一綱十目疏) and “Eight Regulations for Advance and Cultivation" (Jinsupalgyu 進修八規)— memorials to the Throne-are the other writings which well show Li Eonjeok's philosophy of statecraft. Here, the "One Principle" means a ruler's mind-the foundation from which politics comes-and the "Ten Provisions" are concrete methods for governing a state like "strictly managing a family" (the first provision). In the second memorial, he stressed the principles of real kingcraft and these are the basic conditions for being obedient to the Heavenly Way, to make people's mind in peace, and to cultivate the nation's foundation.

Yi Hwang's Statecraft ideas are expressed clearly and concisely in the "Six-Article Memorial” (Mujinyukjoso 戊辰六條疏), (Lee 1974, 9-39) which he addressed to the newly enthroned young King Seonjo (1567-1608). The first article says that "succession to the throne by adoption must be treated as very valuable. In this case, Humanity and Filial Duty (Hyo 孝, Chin. Xiao) must be in deep consideration." The second, "slandering family must be forbidden and both parents by blood as well as adoptive should be respected." Thus, the first and second article request not only that the king keep the royal family well cared for, but also that he place leadership by pubic conscience ahead of private interests, the balance and the unity of people and setting an example to others as the preceding condition in the rule of right. The third article says that "the learning of the monarch must be promoted to further develop the foundation of politics." In this article, we can find the leadership of the governor's thoughts on justice, on setting the sense of value to suit the time and history, and on cultivating emotional intelligence through governor's internal and moral training. Further, the fourth article says that "a ruler has to be well aware of the method how to realize the moral Way ( $D_{0}$ 道, Chin. Dao) to get to people's minds." In other words, perceived truth before institutional reformation and drove away heretical views confusing people's mind, and the politics for people integration by establishing rightly people's mind. The fifth says "to entrust state administration to ministers and to keep good communication with them", which shows that a ruler must trust his officials and not decide arbitrarily.

22 They are: 1) self-cultivation (Susin 修身, Chin. xiushen); 2) respecting the sages (Jonsin 尊腎, Chin. Zunshen); 3) loving kinfolk (Chinchin 親親, Chin. Qinqin); 4) revering the ministers of state (Gyeongdaesin 敬大臣, Chin. Jingdachen); 5) acquiring the officials' mind (Chegunsin 體群 臣, Chin. Tiqunchen); 6) loving the people (Jaseomin 子庶民, Chin. Zishumin); 7) dealing well the craftsmen (Raebaekgong 來百工, Chin. Laibaigong); 8) winning over the hearts of men living far countryside (Yuwonin 柔遠人, Chin. Rouyuanren); and 9) stabilizing the local feudal lords (Hoejehu 懷諸侯, Chin. Huaizhuhou). 
This article deals with the capacity for the governor's tolerance through an open dialogue and the importance of selecting the fittest people for public duty. Finally, he pointed out that "a ruler must practice moral cultivation with sincerity and examine himself to follow Heavenly charity (Cheonae 天愛, Chin. Tianai).” In the sixth article, there was the realization of mind-loving people, keeping an eye on the abuse and corruption of governor's power, and assuming responsibility for people by the name of the authority of Heaven's decree with the harmony of the governor's power and the people's power.

Yi Hwang's political idea is to make the king as a sage. Because he believes that the innate nature of human beings is good, he stresses the cultivation of mind and morally honorable action more than external control and surveillance. It is said that Yi Whang's "Six-Article Memorial" was the condensed output of statecraft based on the "Great Learning" (Daehak 大學, Chin. Daxue) and the "Doctrine of the Mean (Jungyong 中庸, Chin. Zhongyong)”. (Keum 2002, 103-4)

The late 16th century was the period when social contradictions were accumulated to claim the demand of its reform. Yi Yi stated squarely that the society had a lot of contradictions and clearly presented his idea of the "Political Reformation Project (Gyeongjangron 更張論)". Especially, in his memorial to King Seonjo in 1573, he insisted on reforming degenerated politics for the people's stabilization of livelihood. Accordingly, two goals of the Project were: 1) improvement of the moral fiber of government officials and 2) betterment of the people's standard of living. To realize the goals, Yi Yi paid sincere attention to two methods-both subjective and objective. (ibid. 1997, 109-10) The subjective one is the steadfast aim of completing the project and the objective is the reformation of evil practices. That means the two structures of individual self-cultivation-steadfast aim and reflection to improve temperament-and state reformation of evil practices are coincident with each other. Namely, both Individual Cultivation (Suyangron) and Statecraft ideas (Gyeongseron) seemed to be in consistency in the substance of "Nature and Principle". So, he systemized the way of correcting unrighteous ideas in the basis of his theory of $R i$ and $G i$.

Yi Yi emphasized $R i$ as a universal standard. He said that "Nothing is more important for a ruler to enlighten $R i$ in an emergency."This standard of $R i$ in a state reality is the very official discipline which is, at the same time, the thread of life as well as the state's vital energy. Thus, everything must remain in good order in the case of tight discipline, whilst all the laws and systems become abolished in vice versa. In this context, the legislation of the discipline must be supported by the consensus of public opinion (Gongron 公論) and the fixed line of national policy (Guksi 國是). Gongron must have the agreement of all people so as to 
not be determined by individual desire or perception. (Yi 2002, 361-72) Also, Guksi should be all the people's assertion, unspoken affirmation. For Yi Yi, these Gongron and Guksi should be decided not by those in power but by the people who are in charge of Neo-Confucian ideology.

Based on the "Science of Changes" (Yeokbak 易學, Chin. Yixue), Yi Yi presented the term of “timely suitability" (Siyi 時宜), which is the justice principle in the reality of time. He defined the Siyi as the "timely versatility to relieve the people with proper laws." (Yunyeon 1995, 193-5) In other words, it does not mean that the transcendental and unchangeable principle exists, but it is more possible to relieve people in a changing reality. That is the very unity in which $R i$ and $G i$ are inseparable, and is also the principle of Statecraft (Gyeongseron) in which only $G i$ (not $R i$ ) is emanated. Moreover, his statecraft pursuing the unity of the principle and reality leads to the ideal Individual Cultivation (Suyangron) of Sincerity (Seong 誠, Chin. Cheng).

Jeong Yakyong (1762-1836) was the greatest scholar in the late Joseon dynasty. Taking the representative position in Practical Learning (Silhak 實學), he was distinguished in so many fields of study, since he wrote more than 500 books and a lot of memorials to the throne. It is generally agreed that he based his statecraft studies on classical studies such as the Four Books ${ }^{23}$ and Five Classics ${ }^{24}$ (Saseo Ogyeong 四書五經, Chin. Sishu Wujing). (see Keum 2001) Besides, it may be said that Jeong presented an original philosophy of his own by critically incorporating, synthesizing, and creatively restructuring the diverse ideological currents of the time, which included Neo-Confucianism of “Zhuzi's Science” (Jujahak 朱子學), “Wáng Yángmíng’s Science”(Yangmyeonghak 陽明學), “North Learning” (Bukhak 北學), and “Evidential Research” (Gojeunghak 考證學). Jeong Yakyong's theory of statecraft and his reform ideas were well compiled in his trilogy of works- the Design for Good Government (Gyeongseyupyo 經世遺表), Admonitions on Governing the People (Mokminsimseo 牧民心書), and Toward a Nerw Jurisprudence (Heumheumsinseo 欽欽新書) dealing with governing people.

Jeong thought that the government organization, political system, and social institutions of the Joseon dynasty in the early 19th century should be reformed at the base. In the "Design for Good Government", which is the most representative writing of his view on Gyeongron, he designed the new bureaucracy organization,

23 They are: Great Learning (Daehak 大學, Chin. Daxue); Doctrine of the Mean (Jungyong 中庸, Chin. Zhongyong), Analects (Noneo 論語, Chin. Lunyu) and Mencius (Maengja 孟子, Chin. Mengzi).

24 They are: Classic of Poetry (Sigyeong 詩經, Chin. Shijing), Book of Documents (Seogyeong 書經, Chin. Shujing), Book of Rites (Yegyeong 禮經, Chin. Lijing), Book of Changes (Yeokgyeong 易經, Chin. Yijing) and Spring and Autumn Annals (Chunchu 春秋, Chin. Chunqiu). 
which emphasized the kingly government (Wangjeongron 王政論) that he pursued and the approach to seek a way of managing the public authority and politics transparently. He showed two tasks in this book: (see Keum 2001,129: 61-136)1) the comprehensive reformation of the national system according to a new standard and 2) the utmost possible uplift of productivity in all parts of industries. The former was to get rid of long-established conventions and irrationalities. The latter was to overcome the stagnation by the ruling class' exploitations.

The core concept for realizing his statecraft ideas was presented in his Admonitions on Governing the People in which Jeong proposed "Six Statues of Governance" (Yukjeon 六典) (see Song 2009, 24: 57-81) in detail, showing his functional intent for the state's practical operation. This book is a meticulous manual for district magistrates on how to better govern people by using your heart. The first "Statute on Personnel (Ijeon 吏典)" refers to the appointment of upright officials, those who are out of powerful families' influence. In the second "Statute on Taxation (Hojeon 戶典)", he suggested the "Communal Farming Land System (Yeojeonje 閭 田制)" as a reformative land policy. According to the system, only those who actually cultivate the land-actually engaged in agriculture-may possess the land. This system represents his idea of the real farmers' (who are actually engaged in agriculture) exclusive ownership of farmland. In other words, he aims to abolish landowners' excessive ownership. The system is to be operated by this principle: distribution by the amount and contribution of labor. It may be seen something similar to the socialist ideal, but as a matter of fact, the system has more to do with Kibbutz in Israel (the combination of Zionism and socialism); thus, it might be said that it is some kind of combination of Confucianism and socialism. The third "Statute on Rites (Yejeon 禮典)" refers to the Rituals written for the purpose of people's edification and refining the custom. The fourth "Statue on War (Byeongjeon 兵典)" aims at the well-fortified Defense System and the fifth "Statue on Punishment (Hyeongjeon 刑典)" pursues social justice thorough strict and fair law enforcement. The last "Statue on Manufacturing (Gongjeon 工典)" aspires towards innovation and a popularization of technology. It is the highest possible increase in productivity of all parts of industries so as to overcome the stagnation by the ruling class' exploitations.

“Admonitions on Governing the People" emphasizes integrity (Cheongryeom 淸 廉), frugality (Jeolyong 節用), and love of the people (Aemin 愛民) as the cardinal virtues of civil servants. The virtues are meaningful and universal even to modern society. ${ }^{25}$ Although this book is based on the social and political scene of the nine-

25 It is well-known that this Admonitions on Governing the People was late Ho Chi Minh's favorite book as to keep at hand, even in his final days. 
teenth century of Joseon dynasty, the many cases of irregularity and inefficiency among local governments described by Jeong are perennial, as is the quest of a civilized state toward achieving a government that might effectively manage such aberrations. (Choi 2010)

\section{Concluding Remarks}

The Neo-Confucian sprit was the most deeply soaked, the most broadly spread among Koreans, and it provided them with ideology, norms, and a lifestyle that was most strongly functional. Meanwhile, there lie piles of extensive historical records resources, intense academic achievements, and marvelous artistic works. However, since a thought is always activated and functions through history, it is worthwhile to examine the process of how Korean Neo-Confucianism combined with historic and social conditions and, as a result, what kind of properties were formed.

There are some specific characteristics of the tradition of Joseon (Neo)-Confucian thought, compared to that of China. The Korean spiritual climate, social conditions, and the developmental aspects of national history were accordingly quite different in Korea than in China.

Firstly, whereas the Chinese Confucian thought developed toward the more cosmological, centrifugal, and outward, the Korean one was condensed rather into an anthropological, centripetal, and inward way such as the "Four-Seven" theory and Human Nature in the Horak debates. Such a philosophy of anthropological tradition, connected with sanctity of human life, exerted a strong influence on Korean people's moral value, consciousness, and its practice.

Secondly, while Chinese Confucian thought had a more reasonable and practical tendency, Koreans pursued to seek religious and ethical legitimacy under the name of Confucian teaching. The inherent and endogenous elements in Koreans' mentality made it possible to internalize ( $\mathrm{Neo}^{-}$)Confucianism to the synthetic and inspiratory level of mysteriousness, beyond logical rationality.

Moreover, Chinese Confucian thought rather stressed the importance of Humanity - the Confucian gentleman's status. On the other hand, Joseon Neo-Confucian literati put much more emphasis on Righteousness and Fidelity in a macroscale. Making dynamic links with the Neo-Confucian Joseon literati's spirit which denies coercive power and respects right way of Confucian order, it became historically the pivotal ideology of the society.

Last but not least, the spirit of the Joseon literati's Righteousness made the theoretic speculation on moral propriety clear, completely different from the Japanese 
one, which just admires warriors' braveness for victory. It was the very sprit that faced up and struggled to resist foreign invasions. Moreover, the Neo-Confucian ethical intellectualism, rampant in Joseon society, made it possible to encourage this spirit for over five hundred years.

\section{References}

Ching, Julia. 1985. "Yi Yulgok on the "Four Beginnings and the Seven Emotions." In The Rise of Neo-Confucianism in Korea, edited by Wm. Theodore De Bary and Jahyun Kim Haboush. NewYork: Columbia University Press.

Choi, Byonghyon. 2010. “Translator's Introduction.” In Admonitions on Governing the People, edited by Yagyong Chong. CITY: University of California Press.

Fan, Ruiping. 2012."Confucian Ritualization: How and Why?" In Ritual and the Moral Life: Reclaiming the Tradition, edited by David Solomon et al., 143-58. New York: Springer Science \& Business Media.

Fung, Yu-Lan. 1976. A Short History of Chinese Philosophy: A Systematic Account of Chinese. New York: The Free Press.

—. 2007. The Four Books. The Basic Teachings of the Later Confucian Tradition. Indianapolis Hackett Publishing.

Huang, Sui-chi. 1999. Essentials of Neo-Confucianism: Eight Major Philosophers of the Song and Ming Periods. London: Greenwood.

Jo, Gwangjo 조광조. 1988. “Jeongamjip 정 암집.” In Hankuk munjib chong-gan 한국문집총간. Seoul: Minjok munhwa chujinhoe.

Keum, Jang-tae 금장태. 1997. Joseon jeongiy yuhaksasang. 조선 전기의 유학사상. Seul: Seoul National University Press.

- 2001. Tasan Sirak T'amgu 茶山實學探求. Seoul: Sohaksa.

—. 2002. Hankkuk Jongyo Sasangsa II. 韓國宗敎思想史. Part One. “Yugyo Sasangsa” 儒敎思想史. Seoul: Hankuk Saksul Jeongbo.

Kim, Nak Jin 김낙진. 2009. "In-mul-sung-dong-i-Lon Bigyo 정시한, 이식 과 이간, 한원진 인물성동이론 비교.” Hankuk cheolhag nonjib 한국철학논집 26: 151-83.

Lee, Hyo-Dong. 2014. Spirit, Qi, and Multitude. A Comparative Theology for the Democracy of Creation. New York: Fordham Univ. Press.

Lee, Sangeun. 이상은. 1974. "Toegye Myeongjeo Yeokhae 퇴계명저 역해: 무진 6조소.” Toeg yehagbo 퇴계학보 2: 7-39.

Song, Nak Seon 송낙선. 2009. "Dasanyi haengjeonggaehyeokrone daehan hyeondaejeok jomyeong 다산의 행정개혁론에 대한 현 대적 조명." Hankuk hangjeongsa hakji 한국 행정사학지 24: 57-81. 
Yi, Tong-in 이동인. 2002. Yulgok ŭi sahoe kaebyǒk sasang 율곡의 사회개혁 사상. Seoul: Paeksan Sŏdang.

Yi, Hwang 李滉. 1985. Jeungbo Toegye Jeonseo 增補退溪全書, vol. 16. Seoul:

Daedong Munhwa Yeonguwon. Sungkyunkwan University.

Yi, Yi 李珥. 1988. Yulgok Jeonseo. 栗谷全書. Minjok Munhwa Chujinhoe.

Yu, Yingshi 余英时. 1992. Neizai chaoyue zhilu 内在超越之路. Beijing:

Zhongguo guangbo dianshi chubanshe.

Yuksel, Diana. 2013. "Korean Confucian Moral Self-Accomplishment and Postmodern Ethics.” Studia UBB Philologia LVIII (1): 173-84.

Zhu, Xi 朱子. 1986. Zhuzi yulei 朱子語類. Beijing: Zhonghua Shuju. 